\title{
Federal Labour Inspectorate Principles of Activity: Certain Aspects of Their Implementation
}

\author{
Apollinariya Alexandrovna Sapfirova \\ Federal State Educational Institution of Higher Professional Education "Kuban State Agrarian University", \\ Krasnodar, Russian Federation \\ Email:pol499@yandex.ru
}

\section{Viktoria Vladimirovna Volkova}

North Caucasian branch of the Federal State Budget Institution of Higher Professional Education "Russian Academy of Justice", Krasnodar, Russian Federation

Email: www.truba.ru@mail.ru

\section{Anna Vasilievna Petrushkina}

North Caucasian branch of the Federal State Budget Institution of Higher Professional Education "Russian Academy of Justice", Krasnodar, Russian Federation Email: joesline@yandex.ru

\section{Doi:10.5901/mjss.2015.v6n2s4p9}

\begin{abstract}
In the article the general principles of the Federal Labour Inspectorate activity (such as legality, objectivity, independence, publicity) are reviewed. To our mind, the Russian Federation Labour Code should include principled positions which would reflect the essence of Federal Labour Inspectorate activity (principle of centralization, territorial and sectorial exercise of authority, due diligence priority, cooperation with state and local government authorities, civic institutions as well as with employees, employers and their representatives).
\end{abstract}

Keywords: Federal Labour Inspectorate, territorial and sectorial principle, due diligence priority, centralization.

\section{Introduction}

Federal Labour Inspectorate is an executive body that exercises Federal Government Supervision of observance of the labour legislation and other regulations, which contain labour law norms. The main Federal Labour Inspectorate positions (principles) are respect, observance and protection of human and citizen rights and freedoms, legality, objectivity, independence, publicity (part 1 Article 355 Russian Federation Labour Code (hereinafter referred to as RF LC).

\section{Methodology}

Federal Labour Inspectorate main positions of activity stated in part 1 Article 355 of RF LC have a general character.

1. The principle of legality is the principle on the base of which the activity of the whole state authorities system is built. It covers the essence of their activity. Until recently scientists treated legality as the demand of a strict, steadfast abidance and implementation_of all legal regulations and instructions by all the subjects (Alekseev, 1987). Today the legality principle content has undergone some changes: legality presupposes legislation content evaluation, which is expressed in justified and unjustified law representation in acts of a state legislation (Andrianovskaya, 2009) (law and morality unity, observance of a legal duty by all the subject of law (Anisimov, 2004)). Beyond doubt, Labour Legislation should be justified. And at the same time a regulation which allows to sign a fixed-term employment contract with those who are employed by entrepreneurs should be hardly accepted as reasonable (p.2 article 59 RF LC).

However the above mentioned does not mean that legality should depend on either justified or unjustified law. It should be highlighted that for centuries the idea of justice has been changing: what was justified in slave- 
owing system is absolutely unacceptable under existing conditions of development. That is why reasonable laws of the imperial Russia cannot be equally justified for modern Russia.

Violation of law leads to the balance shift between a certain legal norm and its exercise. Legality characterizes legal reality from the point of view of practical usage of a law. Justice has a shade meaning of legality which shows the reason why the exercise of a certain law norm does not reflect or partially reflects existing public relations. Thus, it is difficult to treat labour legislation as justified or unjustified. And what is more, putting its application in dependence from justice, from our point of view, is not completely right as it will have a negative effect on legality principle firmness as a demand for stringent and strict compliance with labour legislation and other regulatory legal acts which contain labour law norms. Justice can occur in such cases as, for example, a size of a fine imposed under administrative law on a public individual for violating labour legislation within a certain sanction (from 30000 to 50000 RUB).

Only competent state authorities should reestablish the rule of law. Judicial authority and public prosecution office, Federal Labour Inspectorate and etc. belong to a number of state authorities which demand statutory compliance of labour legislation and of other regulatory legal acts containing labour law norms.

2. The principle of independence is one of the principles which Federal Labour Inspectorate should base its activity on. Thus, State Labour Inspectors' principle of independence is rather relative. In the process of supervision by the Federal Labour Inspectorate the principle of independence is applied to regulated objects while it is difficult to name its 'inner activity' as independent: labor inspectors formal notes (such as decisions, improvement notes) can be cancelled according to RF LC, Administrative Offences Code of the Russian Federation or by the higher authorities. In such manner, the principle of independence is one of the conditions of Federal Labour Inspectorate activity, but its content should be treated as an "external" independence from federal state supervision objects, i.e. employers. This independence should be granted by the body which Federal Labour Inspectorate is accountable to, in other words to Federal Labour and Employment Service.

3. The principle of objectivity implies protection of employees' labour rights and at the same time observance of an employer's legal interests and is presented in Article 358 RF LC.

4. The principle of publicity aims at the full coverage of the Federal Labour Inspectorate activity concerning employees' labour rights protection. This principle is reflected in the Federal Law concerning "Granting the Access to the Information on State Authorities Activity and Actions of Local Government Authorities" (Federal Law, 2009). According to this regulatory legal act, the whole Federal Labour Inspectorate activity is presented in the Internet. Due to this fact it has become more approachable both for employees and employers to acquire more information on the subject.

\section{Results and Findings}

It should be noted that the above mentioned principles of Federal Labour Inspectorate activity can also characterize any other executive authority, including any federal government supervision authority. Unfortunately, this list of principles does not reflect the specific nature of Federal Labour Inspectorate activity, which leads to the lack of the consistent approach to the essence of Federal Labour Inspectorate activity.

It is thought that p.1 Article 355 RF LC should be supplemented with the principles which have not been established in this regulation, but which are crucial for Federal Labour Inspectorate activity. For example, M.D.Sobyanina offers to include the principle of cooperation between labour inspectors and employers or their unions into the list of Federal Labour Inspectorate activity principles (Sobyanina, 2006).

Introduction of these principles corresponds to Article 5 of International Labour Organization Convention №81 (ILO Convention). Meanwhile the term "cooperation" does not fully reflect the essence of the federal state supervision, which is performed by Federal Labour Inspectorate. It seems more accurate to include into the list of Federal Labour Inspectorate activity principles the principle of Federal Labour Inspectorate cooperation with state and local government authorities, civic institutions as well as with employees, employers and their representatives.

We also offer to reflect the principle of centralization, territorial and sectorial principle as well as due diligence priority principle in p.1 Article 355 RF LC.

1. The territorial and sectorial principle reflects efficiency of Federal Labour Inspectorate activity the best of all. Earlier in the middle of the XX century, when legal, technical and sanitary inspections existed in the body of Labour Inspectorate, only legal inspection activity was based on the territorial principle, the rest of special inspections functioned according to the sectorial principle. The fact that one and the same body was based on such different principles had usually a negative effect on their cooperation and eventually on the result of their 
relations and on the quality of checks. Those few scientists who researched Labour Inspectorate activity were right in paying attention to the necessity of a combined principle application i.e. territorial and sectorial (Gudkov, 1974), which adequately reflects current Labour Inspectorate activity.

2. The principle of due diligence priority. Its inclusion is stipulated by the necessity to ensure, first of all, Labour Inspectorate activity with the aim to protect labour rights in the process of due diligence. Due diligence is checks that include supervision of the observance by employers all the Labour Right Institutions. Already in XX century there was centralized introduction of entrepreneurs' due diligence regulations. In 1926 inspections were allowed to define the regulations of such checks, but on the condition that they would spend no less than 16-18 working days a month on employers' due diligence. People's Labour Commissariat was responsible for the supervision of due diligence observation (Gudkov, 1974).

Today it would be appropriate to return this into practice and introduce centralized regulations of due diligence by government labour inspectors because under the current conditions there is a shift in Federal Labour Inspectorate activity towards conducting special-purpose inspections (dealing with employees' applications) the number of which has risen during the previous years. Otherwise, the main purpose of Federal Labour Inspectorate will become obsolete, i.e. to prevent employees' labour rights abuse, i.e. supervision conducted before wrongdoing. It should be noted that the analysis of modern applications by employees to Federal Labour Inspectorate shows that they (applications) correspond to $3 / 4$ of scheduled inspections (Federal Labour [FL], 2010; FL, 2012). It means that scheduled inspections, which have compulsory character and should be main for Federal Labour Inspectorate, make $1 / 4$ of all the inspections.

3. The principle of centralization. Today Federal Labour Inspectorate is subordinate to Federal Labour and Employment Service (RF Government Decree [RF GD], 2004), which in its turn is subordinate to Ministry of Labour and Social Protection (RF GD, 2012). One can say that Inspectorate is in unit relation with this federal service. Head of Federal Labour and Employment Service (Head of Federal Labour Inspectorate) is the Russian Federation Chief State Labour Inspector and he or she can be promoted to the position or removed from the office by the Russian Federation Government (Article 354 RF LC). This current subordination should be reviewed within the framework of its accordance with the provisions of the ILO Convention №81.

According to Article 4 of ILO Convention №81 Labour Inspectorate should be under supervision and control of the central authority. i.e. the central authority of a federation or a central authority of one of the parts which comprise a federation. The question has arisen "What authority should be treated as the central authority of the Russian Federation?"

According to the soviet legislation and, first of all, the USSR Constitution of 1977, by central authorities, as a rule, central authorities of government administration were implied (Articles 135, 136 of the USSR Constitution), in particular, ministries, state committees and etc. Up to the end of XX century if central authorities were mentioned in special literature, ministries and other central authorities of government administration were meant instead.

Nowadays it is clearly stated in the RF Constitution that legislative, executive and judicial branches of authority are self-determined (Article 10 of the RF Constitution). It means that any authority belonging to legislative, executive and judicial branches as well RF President can be acknowledged as the Russian Federation central authority.

Probably (at least we drive our conclusion from this assumption), according to ILO Convention №81 the main state authority body is the central authority of a federation. By no means it is impossible to try to find the main branch among three branches of authority and the main state authority corresponding to it would contradict the RF Constitution. Thus, it is necessary to define the state authority which would provide Federal Labour Inspectorate with maximum independence not only from other state authorities but from the authority it would be subordinate to.

It stands to reason that it is impossible to make Federal Labour Inspection subordinate to judicial authorities because they have different aims, functions and purposes. If a federal government supervision authority was subordinate to legislative authority it would not correspond to inspection supervision activity.

It means that Federal Labour Inspectorate can equally be subordinate to RF President as well as to executive authority bodies.

According to the existing legislation RF President runs certain federal ministries, federal services and agencies, the structure of which states their "forceful" character (Russian Federation President Decree, 2012). Federal Labour Inspectorate cannot be referred to such federal services because the aim of its activity is socially oriented and connected with the protection of labour rights. Therefore, it would be unreasonable to make Federal Labour Inspectorate subordinate to the RF President.

Thus, it is sensible to make Federal Labour Inspectorate subordinate to one of the executive authorities. Today Federal Labour Inspectorate subordination to the Federal Ministry via Federal Labour and Employment Service contradicts ILO Convention №81 which demands Federal Labour Inspectorate direct subordination to the state 
centralized authority. Federal Labour Inspectorate should be an independent executive authority which is subordinate to the state centralized authority. To exercise international regulations Federal Labour Inspectorate should cease to be subordinate to Federal Labour and Employment Service and become subordinate either to the Ministry of Labour and Social Protection or to the RF Government. Provided however that the latest changes in RF LC (Federal Law, 2011) allow us to assume that subordination of Federal Labour Inspectorate to the RF Government is reasonable. At the same time, having focused on the existing system and structure of the federal executing authorities, Federal Labour Inspectorate should be named Federal Labour Service, which is subordinate to the RF Government. Only in such a way all the provisions of the ILO Convention №81 would be observed as well as the principle of centralization would find its way.

\section{Recommendations}

Thus, as the result of our research we could offer the following of p.1 Article 355 RF LC: "Federal Labour Inspectorate should base its activity on the principles of respect, observance and protection of human and citizen rights and freedoms, legality, objectivity, independence, publicity, centralization, territorial and sectorial exercise of authority, due diligence priority and cooperation with state and local government authorities, civic institutions, as well as employees, employers and their representatives".

\section{References}

Alekseev, S. S. (Ed.). (1987). Theory of State and Law Issues. Moscow: Juridicheskaya Literatura.

Andrianovskaya, I. I. (2009). Justice in the Modern Legal Reality of Russia. Yuzhno-Sakhalinsk: Sakhalin State University Publishing House.

Anisimov, P. V. (2004). Human Rights and Their Regulations: Theoretical and Practical Problems. Volgograd: VA Interior Ministry of Russia.

Federal Law of February 9th 2009 №8-FL (2009). "Access to the Information Concerning Activity of State Authorities and Local Government Authorities". RF Legislation Collection, 7, article 776, 2011, 29, article 4291.

Sobyanina, M. D. (2006). Principles of Russian Labour Law Institutions (Unpublished master's thesis). Perm State University, Perm, Russia.

Gudkov, V. S. (1974). USSR Legal Labour Inspectorate (Historical and Legal Study) (Unpublished master's thesis). Graduate School of the trade union movement, Moscow, USSR.

Federal Labour and Employment Service Report Concerning State Control (Supervision) of Observance of Labour Legislation and Other Regulatory Legal Acts Which Contain Labour Law Regulations (2010).

Federal Labour and Employment Service Report Concerning Exercise and Efficiency of State Sprvision and Control in the Sphere of Labor and Welfare (2012).

RF Government Decree of June 30th 2004 №324 as revised of December 26th 2011 "Approval of Federal Labour and Employment Service Regulation". (2004). RF Legislation Collection6 28, article 2901.

RF Government Decree of June 19th 2012 №610 concerning "Regulation of the Russian Federation Ministry of Labour and Social Protection Approval". (2012). RF Legislation Collection, 26, article 3528.

Russian Federation President Decree of May 12 2012 №636 "Questions of the System and Structure of Federal Executive Authorities". (2012). RF Legislation Collection, 22, article 2754.

Federal Law of July 18 2011 №242-FL "Making Amends to Certain RF Formal Notes Concerning Questions of State Control (Supervision) and Municipal Control". (2011). RF Legislation Collection, 30, article 4590. 